\title{
Monitoring wizyjny i jego wpływ na straty spowodowane przestępczością. Przykłady z wybranych polskich miast
}

\section{Streszczenie}

W Polsce, podobnie jak w innych krajach, brakuje jednoznacznego i uzgodnionego wyjaśnienia przyczyn obniżenia poziomu przestępczości odnotowanego w ostatnich kilkunastu latach. W artykule analizowany jest wpływ systemów monitoringu wizyjnego na straty powodowane przez trzy kategorie przestępstw: (a) kradzież samochodu, kradzież z włamaniem do samochodu, kradzież z samochodu; (b) uszkodzenie samochodu; (c) rozbój. Aby odpowiedzieć na pytanie, czy instalowanie systemów monitoringu wizyjnego ma wpływ na bezpieczeństwo, badane są ekonomiczne skutki instalowania kamer w ośmiu polskich miastach, w których systemy monitoringu wizyjnego są dobrze rozwinięte (Gdańsk, Katowice, Kielce, Lublin, Łódź, Poznań, Warszawa, Wrocław). Określenie wpływu instalacji kamer na zmniejszenie strat spowodowanych przestępczością pozwala ocenić przydatność kamer dla poprawy bezpieczeństwa publicznego.

Analiza danych przeprowadzona na potrzeby artykułu częściowo potwierdza skuteczność monitoringu miejskiego w zakresie zmniejszania liczby przestępstw w badanych kategoriach. Warto zaznaczyć, że również inne czynniki mogą mieć na to wpływ. Monitoring miejski ma natomiast mniejsze oddziaływanie na straty spowodowane przestępczością. W związku z tym przy ocenie skuteczności monitoringu wizyjnego w obniżaniu poziomu przestępczości poleganie wyłącznie na kryterium liczby przestępstw jest niewystarczające. Słowa kluczowe: monitoring wizyjny, bezpieczeństwo publiczne, straty spowodowane przestępczością

DOI: $10.33119 / \mathrm{KSzPP} / 2020.1 .3$

\footnotetext{
1 Uniwersytet im. Adama Mickiewicza w Poznaniu, Wydział Socjologii; Identyfikator ORCID: 00000003-4730-5904

2 Uniwersytet im. Adama Mickiewicza w Poznaniu, Wydział Socjologii; Identyfikator ORCID: 00000002-8638-0141

3 Uniwersytet im. Adama Mickiewicza w Poznaniu, Wydział Nauk Geograficznych i Geologicznych; Identyfikator ORCID: 0000-0003-4790-5723

4 Uniwersytet im. Adama Mickiewicza w Poznaniu, Wydział Matematyki i Informatyki; Identyfikator ORCID: 0000-0003-1385-6572
} 


\title{
Video monitoring and the level of losses caused by crime. The case studies from selected Polish cities
}

\begin{abstract}
In Poland, similarly to other countries, there is no unambiguous agreed explanation to the reasons for the observed decline in crime. The article analyses the impact of video monitoring systems on losses caused by three categories of offenses: (a) car theft, theft with burglary, theft from cars; (b) damage to cars; (c) robbery. To answer the question whether the installation of video surveillance systems has an impact on security, the economic effect of installing cameras in eight Polish cities (Gdańsk, Katowice, Kielce, Lublin, Łódź, Poznań, Warszawa, Wrocław), where video surveillance systems are well developed, is examined. Determining whether the installation of cameras contributes to the reduction of losses caused by crime allows assessing the suitability of cameras for improving public safety.

The study partially confirms the effectiveness of video monitoring systems for a decrease in crime in the analysed categories of crime. However, other possible factors, in addition to the development of monitoring, may have an impact. Moreover, the impact is less pronounced in the case of the volume of losses caused by crime than the number of crimes. Thus, when assessing public policies regarding security, the number of offenses criterion is insufficient.
\end{abstract}

Keywords: CCTV, public safety, losses caused by crime

Zapewnienie i utrzymanie bezpieczeństwa to jedne z najstarszych i najważniejszych zadań publicznych. Są one intuicyjnie zrozumiałe i zakorzenione w społecznej świadomości, mimo że ich sens jest przedmiotem sporów i dyskusji, zaś definicja prawna nie jest jasno określona (Mączyński, 1998: 185). Przez bezpieczeństwo rozumiany jest stan w państwie, w którym ani konkretnemu człowiekowi, ani ogółowi społeczeństwa nie grozi żadne niebezpieczeństwo, niezależnie od źródła, z którego miałoby ono pochodzić (Sienkiewicz-Małyjurek, 2010: 23-139; Szeląg, 2013: 162). Takie pojęcie bezpieczeństwa ma jednak charakter ogólny i obejmuje między innymi zagrożenia zewnętrzne. W niniejszym artykule przedmiotem zainteresowania są zagrożenia dla bezpieczeństwa powodowane przestępczością. Zagrożenia zewnętrzne nie są uwzględnione w pracy, zaś ważną rolę odgrywają pojęcia bezpieczeństwa publicznego oraz porządku publicznego. Bezpieczeństwo publiczne rozumiane jest jako gwarancja niezakłóconego funkcjonowania obywateli oraz instytucji (Lisiecki, 2009: 13). Z kolei, porządek publiczny definiowany jest jako pewien stan faktyczny wewnątrz państwa, który jest uregulowany normami prawnymi i pozaprawnymi (obyczajowymi 
itp.). Przestrzeganie tych norm umożliwia zgodne współżycie jednostek w organizacji państwowej (Filaber, 2008: 30). Wreszcie, termin „poczucie bezpieczeństwa” opisuje uśrednione subiektywne oceny obywateli odnoszące się do bezpieczeństwa i oparte na indywidualnym doświadczeniu i wiedzy. Należy zauważyć, że zmiany poczucia bezpieczeństwa mogą się wiązać ze zmianami poziomu przestępczości, lecz nie musi to być zależność bezpośrednia.

Choć zapewnienie całkowitego bezpieczeństwa i porządku publicznego jest niewykonalne, zadaniem władz publicznych jest eliminacja zagrożeń dla życia, zdrowia i mienia obywateli oraz dla funkcjonowania ogólnie rozumianego życia społecznego (Czapska, Wójcikiewicz, 1999: 5) w celu stałej poprawy jakości życia mieszkańców. Spełnianie zadań w zakresie bezpieczeństwa publicznego jest obowiązkiem władz publicznych i innych struktur życia społecznego. W szczególności obowiązek ten spoczywa na gminach, co wskazane jest w art. 7 ust. 1 pkt 14 ustawy o samorządzie gminnym ${ }^{5}$.

\section{Monitoring wizyjny jako narzędzie obniżania poziomu przestępczości}

Władze publiczne podejmują działania w zakresie dbałości o bezpieczeństwo, składające się na określoną politykę, która zmienia się w czasie, w zależności od znaczenia nadawanego bezpieczeństwu, od preferencji społecznych, możliwości finansowych i technicznych, uwarunkowań prawnych itd. Nowe możliwości w zakresie polityki bezpieczeństwa publicznego stwarza rozwój technicznych możliwości monitoringu wizyjnego. Technologia ta rozwija się dynamicznie i jest obecnie szeroko stosowana na świecie, $\mathrm{w}$ tym $\mathrm{w}$ wielu miastach $\mathrm{w}$ Polsce. Monitoring ma za zadanie wpłynąć na wzrost poczucia bezpieczeństwa wśród mieszkańców oraz przynieść spadek poziomu przestępczości. Kamery realizują te zadania poprzez wiele pełnionych funkcji (Tilley, 1993): (a) monitoring miejski zniechęca potencjalnych przestępców obawiających się kary spowodowanej zarejestrowanym materiałem; (b) potencjalne ofiary czują się bezpieczniej na obszarach objętych monitoringiem; (c) monitoring pozwala umieścić personel ochrony w miejscach, w których zauważono niepożądane zachowanie; (d) informacja na temat rozmieszczenia kamer monitoringu miejskiego odstrasza przestępców z tych miejsc; (e) monitoring miejski powoduje, że dokonanie

5 Przepis wskazuje, że do zadań własnych gminy należą m.in. sprawy „porządku publicznego i bezpieczeństwa obywateli oraz ochrony przeciwpożarowej i przeciwpowodziowej, w tym wyposażenia i utrzymania gminnego magazynu przeciwpowodziowego"; Ustawa z 8.03.1990 r. o samorządzie gminnym (tekst jedn. Dz.U. 2013, poz. 594 ze zm.). 
przestępstwa staje się trudniejsze i bardziej ryzykowne; (f) lista potencjalnych przestępstw w obszarze nadzorowanym monitoringiem ogranicza się do tych, które można popełnić w krótkim czasie ze względu na możliwość szybkiej reakcji ze strony policji czy straży miejskiej; (g) informacja o działającym monitoringu miejskim powoduje, że ludzie zwracają większą uwagę na swoją własność.

Rozwój monitoringu miejskiego pociąga za sobą wzrost zapotrzebowania na skuteczne metody ewaluacji tych systemów. Od lat na świecie prowadzone są badania na temat tego, czy i w jaki sposób monitoring miejski realizuje wyżej wymienione zadania. Skuteczność monitoringu miejskiego bada się najczęściej za pomocą wskaźnika liczby przestępstw. Wyniki dotychczasowych badań nie są jednoznaczne. Hyungjin Lim wraz ze współautorami (2016) przeprowadzili analizę kilkunastu badań wykonanych w różnych krajach. Analizowane wyniki nie pozwalały na jasne określenie skuteczności miejskich kamer. Pożądany efekt stosowania monitoringu miejskiego został stwierdzony jedynie w przypadku przestępstw samochodowych, takich jak kradzież auta bądź kradzież z auta.

W niniejszym artykule skupiono się na stratach, jakie ponosi ofiara w wyniku przestępstwa i na tym, jaki jest związek monitoringu wizyjnego ze stratami spowodowanymi przestępstwami. Zwrócono w związku z tym uwagę na problem dostępności danych, a także wskazano, jakie dane pozwalają na szczegółową ewaluację monitoringu miejskiego.

\section{Zmiany poziomu przestępczości w Polsce}

Poziom przestępczości podlega fluktuacjom wynikającym m.in. ze zmiennej gotowości do popełniania czynów zabronionych oraz działań władz publicznych i samych obywateli, przeciwdziałających przestępczości. W Polsce, w ostatnim trzydziestoleciu można zauważyć znaczną dynamikę zmiany poziomu przestępczości oraz poczucia bezpieczeństwa obywateli. Poziom przestępczości wzrastał po roku 1989, zaś po roku 2004 można zaobserwować jego spadek (rysunek 1). Transformacja ustrojowa okazała się przełomowym momentem dla poziomu przestępczości oraz poczucia bezpieczeństwa w Polsce, które malało aż do 1995 roku. Kolejna zmiana pojawiła się na przełomie wieków, od kiedy poczucie bezpieczeństwa wyraźnie rośnie (z poziomu 20\% w 2001 roku do 70\% w 2012).

Zauważalny w Polsce spadek poziomu przestępczości wpisuje się w światowy trend (Economist, 2013). W wielu krajach europejskich, jak również w Stanach Zjednoczonych, odnotowano w ostatnich 20 latach spadek poziomu przestępczości. Powody tego zjawiska nie są jasne, a dotychczasowe badania nie dają jednoznacznych 
wyników (Aebi, Linde, 2010; Farrell, i in., 2014; Tonry, 2014; Farrall, 2017). Levitt (2004) w swojej próbie wyjaśnienia znaczącego spadku poziomu przestępczości w amerykańskich miastach w latach 90. XX wieku wskazuje, że największy wpływ na malejącą liczbę przestępstw mają następujące czynniki: (a) rosnąca liczba policjantów, (b) zwiększenie populacji osób znajdujących się w więzieniach, (c) opanowanie epidemii ludzi uzależnionych od narkotyków, (d) legalizacja aborcji.

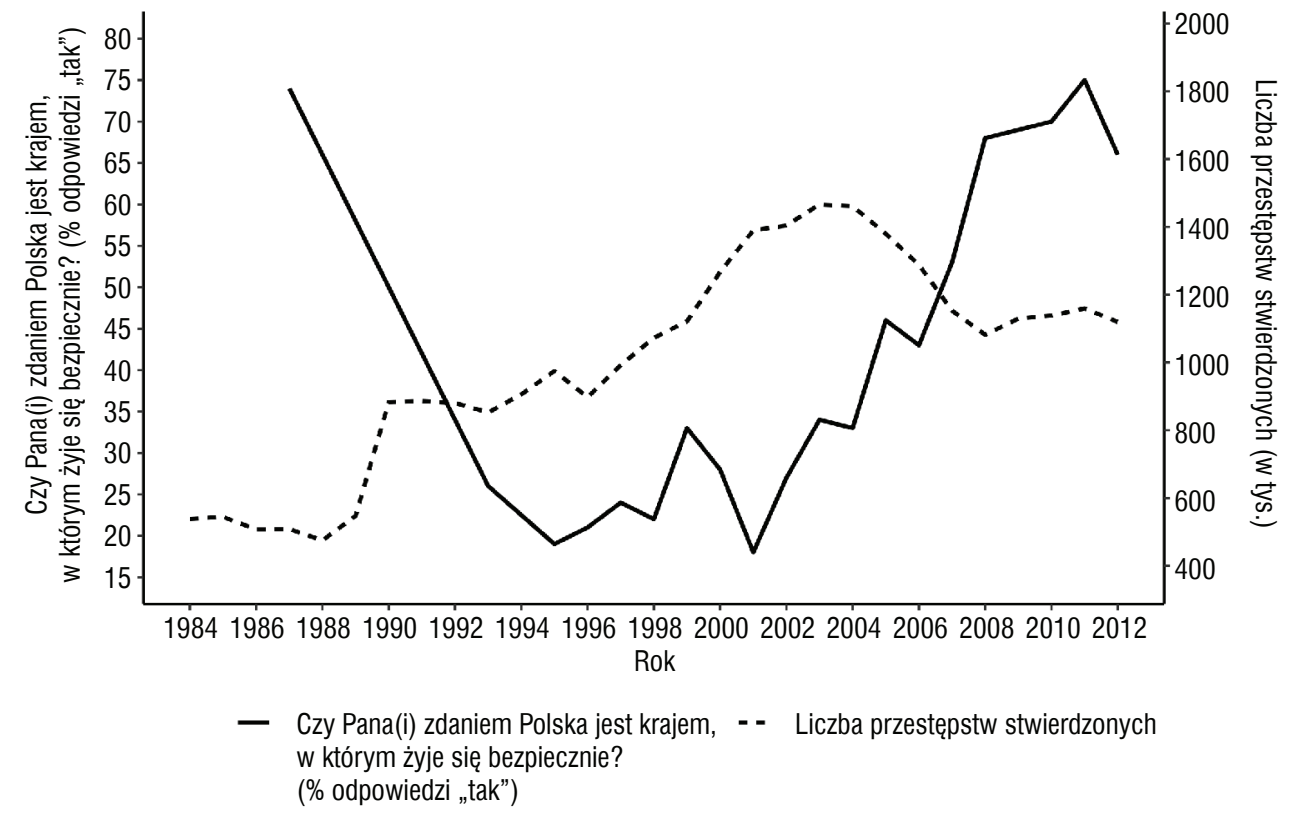

\section{Rysunek 1. Poczucie bezpieczeństwa Polaków oraz liczba przestępstw}

Źródło: CBOS; otwartedane.gov.pl, Szymańczak (1998); Policja (1998).

Z kolei, w Polsce Siemaszko (2015) wskazuje na siedem możliwości przyczyn spadku przestępczości: (a) starzenie się społeczeństwa (osoby starsze są mniej skłonne do popełniania przestępstw), (b) emigracja młodych ludzi z kraju po 2004 r., (c) spadek relatywnej wartości dóbr pożądanych przez przestępców (np. sprzętu AGD), (d) większa skuteczność pracy policji, (e) obecność straży miejskich i służb ochrony, (f) lepsze oświetlenie ulic (prewencja sytuacyjna), (g) instalacja systemów monitoringu wizyjnego (kamer).

Podobnie jak w innych krajach, w Polsce brakuje jednoznacznego i uzgodnionego wyjaśnienia przyczyn obserwowanego spadku przestępczości. W niniejszym artykule poruszono temat jednego ze wskazanych powyżej potencjalnych powodów zaobserwowanej sytuacji, a mianowicie instalacji systemów monitoringu wizyjnego. 


\section{Straty spowodowane przestępczością}

Prewencyjne efekty monitoringu wizyjnego związane są bezpośrednio z ograniczaniem strat społecznych spowodowanych przestępczością. Przestępczość nieodłącznie niesie za sobą występowanie strat i kosztów dla poszkodowanych oraz społeczeństwa. Ich analiza jest częścią podejścia ekonomicznego, zapoczątkowanego w badaniach nad przestępczością przez Beckera (1990), który się koncentrował na ekonomicznej analizie czynników skłaniających do popełnienia przestępstwa. Straty spowodowane przestępczością ( $w$ literaturze utożsamiane z kosztami przestępstw) mają różny charakter. Próby usystematyzowania i kategoryzacji wiedzy dotyczącej typów kosztów przestępczości podjęli się między innymi Dolan i Peasgood (2006), którzy podzielili koszty przestępstw na „koszty namacalne” lub innymi słowy koszty mające swoją wartość pieniężną (na przykład koszt leczenia spowodowany napaścią) oraz „koszty niematerialne”, takie jak zmiany zachowania bądź postrzegania społeczeństwa spowodowane przez przestępstwo. Szczegółową typologię zaproponował również Czabański (2006), który wyróżnił dziesięć typów kosztów związanych z przestępczością: (a) koszty wiktymizacji (obejmujące koszty wymierne, jak np. koszty zniszczonego mienia, jak i koszty trudniej mierzalne, takie jak ból, cierpienie i obniżona jakość życia), (b) koszty zabezpieczeń indywidualnych (zamki itp.), (c) koszty zachowań ostrożnościowych, (d) koszty systemu wymiaru sprawiedliwości, (e) koszty publicznych programów prewencyjnych, (f) trwałe efekty oddziałujące na jednostki (np. strach przed przestępczością), (g) trwałe efekty dla społeczności (np. degradacja okolicy z powodu przenosin zamożniejszych mieszkańców w bezpieczniejsze rejony), (h) koszty nad-odstraszania (tj. koszty działań zaniechanych przez ludzi z obawy o oskarżenie o działalność przestępczą), (i) koszty zapewnienia sprawiedliwości (tj. koszty poniesione w celu upewnienia się, że została wymierzona sprawiedliwość - np. koszty wieloinstancyjnego postępowania karnego, obrońców z urzędu itp.), (j) koszty ponoszone przez uwięzionych sprawców.

Niniejszy artykuł odnosi się do kategorii kosztów wiktymizacji (Czabański, 2006) zawężonej do kosztów związanych ze zniszczonym bądź zrabowanym mieniem. Analiza strat spowodowanych przestępczością jest przydatna dla znalezienia takich metod zmniejszania przestępczości, które będą efektywne w sensie zmniejszania liczby przestępstw oraz opłacalne - w sensie ekonomicznym. 


\section{Monitoring wizyjny w Polsce}

Monitoring wizyjny w polskich miastach rozpowszechniony jest od początku XXI wieku (Lewandowski, Matczak, 2015). Jest on sukcesywnie rozbudowywany, w znaczny sposób powiększając monitorowaną przez kamery powierzchnię miast. Monitoring wizyjny w Polsce nie jest ściśle uregulowany prawnie, zaś rozwiązania ustawowe są przygotowywane. Innym problemem jest brak systematycznie gromadzonych danych na temat systemów monitoringu wizyjnego w Polsce.

Należy zauważyć, że systemy monitoringu są instalowane zarówno w przestrzeni publicznej, jak i prywatnej (w sklepach, firmach itd.). Niniejszy artykuł dotyczy monitoringu w przestrzeni publicznej. Zarządzanie i odpowiedzialność za te systemy zależą od lokalnych decyzji w poszczególnych miastach, jednak najczęściej spoczywają na straży miejskiej bądź Policji. Nie ma przepisów regulujących kwestię, ilu operatorów powinno na bieżąco śledzić obraz z kamer. Pomimo stale rozwijanej infrastruktury w polskich miastach nie przeprowadzono jeszcze kompleksowej i systematycznej analizy efektów działania monitoringu (NIK, 2014).

\section{Dane i metody}

Niniejszy artykuł dotyczy monitoringu wizyjnego w ośmiu polskich miastach (Gdańsk, Katowice, Kielce, Lublin, Łódź, Poznań, Warszawa, Wrocław) w latach 2005-2012. Wybór miast wynika z dwóch powodów. Po pierwsze, miasta te posiadaja stosukowo dobrze rozwinięte systemy monitoringu wizyjnego. Po drugie, decyzja pokierowana była możliwością uzyskania danych na temat przestępczości dla analizowanego okresu. Okres objęty badaniem wynikał z dostępności danych o odpowiedniej jakości, pochodzących od organów administracji odpowiedzialnych za ich gromadzenie i zarządzanie nimi.

Szczególnie istotne w badaniach dotyczących ewaluacji systemów monitoringu miejskiego są dane policyjne dotyczące przestępstw. Nie zawsze są one precyzyjne i wyczerpujące, co wynika m.in. z niedokładności procedur oraz z błędów ludzkich, ale również z samej natury przestępczości, która się nie poddaje łatwo sprawozdawczości (Siemaszko, 2015). Utrudnieniem podczas gromadzenia danych jest również niepewność urzędników oraz funkcjonariuszy co do tego, jaki zakres informacji może zostać przekazany badaczom bądź obywatelom. Problem braku precyzji danych policyjnych znany jest na całym świecie. Badacze starają się niwelować skutki braków, jednak, bez wątpienia, jakość danych komplikuje przeprowadzenie badań 
na temat skuteczności i efektywności kosztowej monitoringu wizyjnego (Waszkiewicz, 2012; Dąbrowski i in., 2018).

\section{Informacje na temat wybranych przestępstw}

Dane dotyczące liczby przestępstw w wybranych kategoriach, jak i strat pieniężnych spowodowanych przez przestępstwa, pochodzą z Komendy Głównej Policji. W niniejszym artykule analizowane są dane dotyczące trzech kategorii przestępstw: (a) kradzieży samochodu, kradzieży z włamaniem do samochodu, kradzieży z samochodu, (b) uszkodzenia samochodu, (c) rozboju (czyli kradzieży połączonej z użyciem przemocy bądź groźbą użycia przemocy). Wybrane przez nas kategorie to tak zwane przestępstwa uliczne. Wykorzystuje się je powszechnie do badania skuteczności monitoringu miejskiego (Welsh, Farrington, 2003; Lim i in., 2016) ze względu na to, że przestępstwa te są widzialne dla oka kamery. Sposób, w jaki skategoryzowane zostały przestępstwa, wynika z przełożenia języka Kodeksu karnego na trzy prostsze kategorie. W zapisie przestępstwa wpisywany jest numer artykułu Kodeksu karnego, do którego przyporządkowane jest zdarzenie. W związku z tym zgromadzone z Komendy Głównej Policji dane zawierały informacje na temat liczby przestępstw dotyczących samochodów popełnionych w ramach artykułu 278kk. Nie zawierały natomiast jasnego rozróżnienia, ile przestępstw dotyczyło kradzieży auta, a ile kradzieży przedmiotu $\mathrm{z}$ auta, ponieważ oba te przestępstwa opisywane są przez ten sam punkt Kodeksu karnego. Brak tej informacji spowodował, że konieczne było stworzenie zbiorczej kategorii (a): kradzież samochodu, kradzież z włamaniem do samochodu, kradzież z samochodu (tabela 1).

Tabela 1. Kategoryzacja analizowanych przestępstw

\begin{tabular}{|c|l|c|}
\hline ID & \multicolumn{1}{|c|}{ Kategoria analizy } & Artykuły Kodeksu Karnego \\
\hline (a) & kradzież z samochodu & 278,279 \\
\hline (a) & kradzież samochodu & $278,279,289$ \\
\hline (a) & włamanie do samochodu & 278,279 \\
\hline (b) & uszkodzenie samochodu & 288 \\
\hline (c) & rozbój & $280,282,284$ \\
\hline
\end{tabular}

Źródło: opracowanie własne na podstawie Kodeksu karnego.

W przypadku kategorii „uszkodzenie samochodu” można domniemywać, że duża część czynów zaliczanych do tej kategorii to przestępstwa popełniane spontanicznie pod wpływem środków odurzających bądź silnych emocji. W terminologii 
prawniczej działania o takim charakterze zapisuje się jako działanie z zamiarem nagłym (Daszkewicz, 1968).

Kategorią przestępstw, która została pominięta w analizie, a która często znajduje się w polu zainteresowania badaczy zajmujących się monitoringiem miejskim, są „bójki i pobicia”. Niestety nie udało się zdobyć danych na temat liczby i kosztów przestępstw dotyczących tej grupy.

Zgromadzone dane zawierają informacje o liczbie przestępstw popełnionych w każdym roku w ramach wymienionych wyżej kategorii oraz łącznej wielkości strat, jakie poniosły ofiary w wyniku przestępstw. Wykorzystano liczby przestępstw stwierdzonych, czyli zdarzeń, które po postępowaniu przygotowawczym określono jako przestępstwo. Zatem prezentowane dane nie obejmują wszystkich zdarzeń zarejestrowanych przez Policję, a jedynie te czyny, które w postępowaniu uznano za przestępstwo.

Największym mankamentem prezentowanych danych jest ich aktualność czasowa. Dotyczą one lat 2009-2012. Nadesłane przez Policję dane były niepełne oraz zapisane $\mathrm{w}$ dwóch różnych systemach. Dane dotyczące przestępstw popełnionych do 2012 roku były zliczane $\mathrm{w}$ inny sposób niż te $\mathrm{z}$ lat późniejszych. W przypadku danych z kategorii „uszkodzenia” zgromadzone zostały informacje dotyczące liczby przestępstw oraz wielkości strat wynikających z popełnienia przestępstwa w ośmiu badanych miastach w okresie od 2005 do 2015 roku (zgodnie z naszą prośbą). W przypadku kategorii „rozbój” uzyskano dane obejmujące lata 2005-2012. Danych dotyczących przestępstw z późniejszych lat nie udało się zdobyć. Dane z kategorii (a) kradzieży samochodu, kradzieży z włamaniem do samochodu, kradzieży z samochodu okazały się częściowo wybrakowane, tj. do 2012 roku przesłane przez Policję pliki zawierały wszystkie dane, o które wnioskowaliśmy, natomiast z lat 2013-2015 są one niepełne, co powoduje, że niemożliwe było włączenie ich do analizy.

\section{Rozwój monitoringu wizyjnego}

W Polsce monitoring wizyjny budowany jest najczęściej z inicjatywy samorządów. Władze gmin nie tylko odpowiadają za powstanie systemu monitoringu, ale także nim zarządzają. Do obsługi i monitorowania obrazu z kamer najczęściej delegowana jest straż miejska.

Monitoring polskich miast rozwija się dynamicznie. W ośmiu wziętych do analizy miastach w 2005 roku sumarycznie zainstalowanych było zaledwie 35 kamer, zaś w 2015 r. było ich już 1447 (rysunek 4). Liczba kamer monitoringu miejskiego w poszczególnych miastach w badanym okresie zwiększała się systematycznie, choć nie w sposób liniowy. Budowa monitoringu miejskiego odbywa się najczęściej etapami. 
Oznacza to, że w danym roku w jednym mieście może się pojawić nawet kilkadziesiąt kamer, podczas gdy inne miasto może akurat nie rozbudowywać swojego systemu. Mimo to, uśrednienie danych ze wszystkich miast pokazuje systematyczny przyrost.

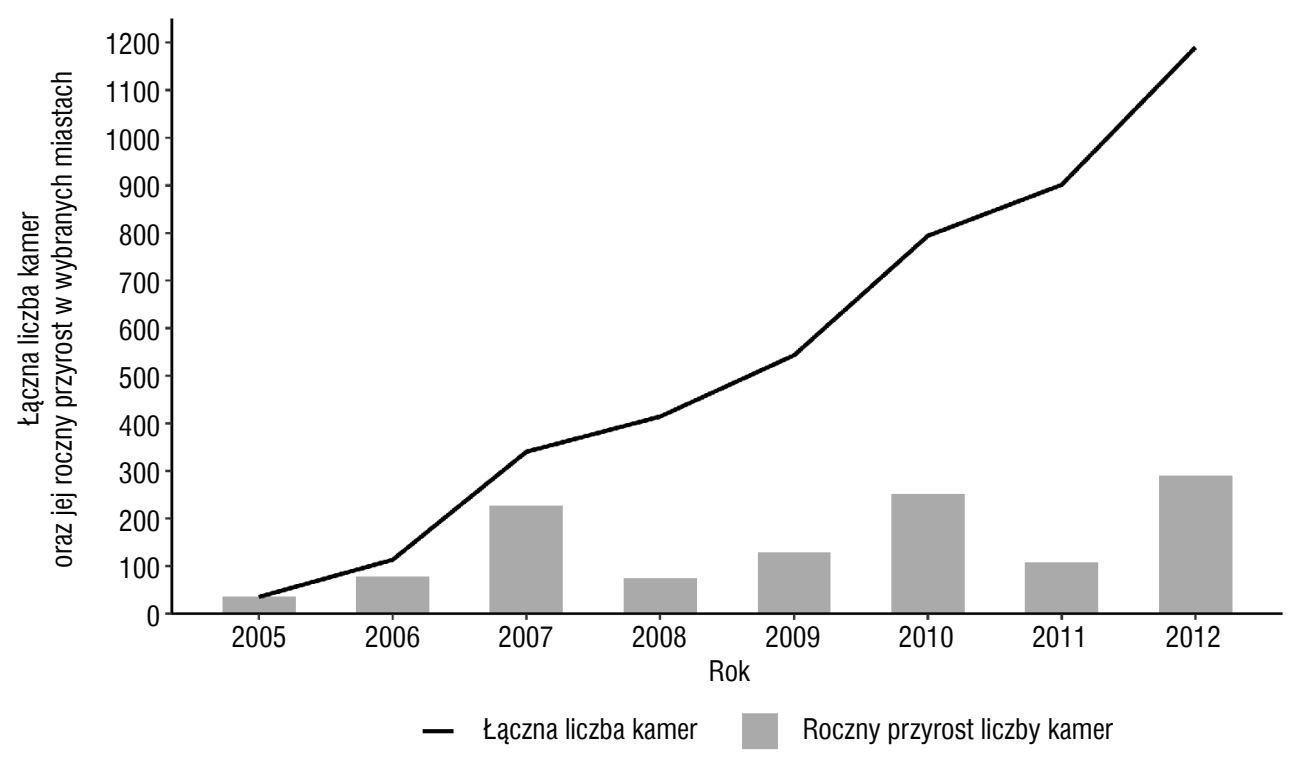

Rysunek 2. Roczne przyrosty liczby kamer oraz skumulowana liczba kamer w ośmiu badanych miastach

Źródło: opracowanie własne na podstawie danych Policji.

Widoczne na rysunku 2 znaczne przyrosty kamer w latach 2010 oraz 2012 mogą być związane $\mathrm{z}$ dużymi naciskami na zapewnienie bezpieczeństwa w czasie organizowanych przez Polskę i Ukrainę Mistrzostw Europy w Piłce Nożnej Euro 2012.

\section{Wyniki analizy}

W ciągu ostatnich dwudziestu lat w Europie obserwuje się generalny spadek liczby przestępstw. Podobne zjawisko zaobserwować możemy także w Polsce. Linie trendu dla wybranych w niniejszym badaniu kategorii przestępstw pokazują, że największe zmiany dotyczą przestępstw samochodowych (rysunek 3). Linia trendu dla kategorii „rozbój” również jest spadkowa, jednak o mniejszym kącie nachylenia. Kategorią zmieniającą się w najmniejszym stopniu jest „uszkodzenie samochodu”. W przypadku tej kategorii linia trendu nieznacznie idzie w górę, co oznacza, że od 2005 do 2012 roku łączna liczba tych przestępstw w ośmiu badanych przez nas miastach wzrosła. 


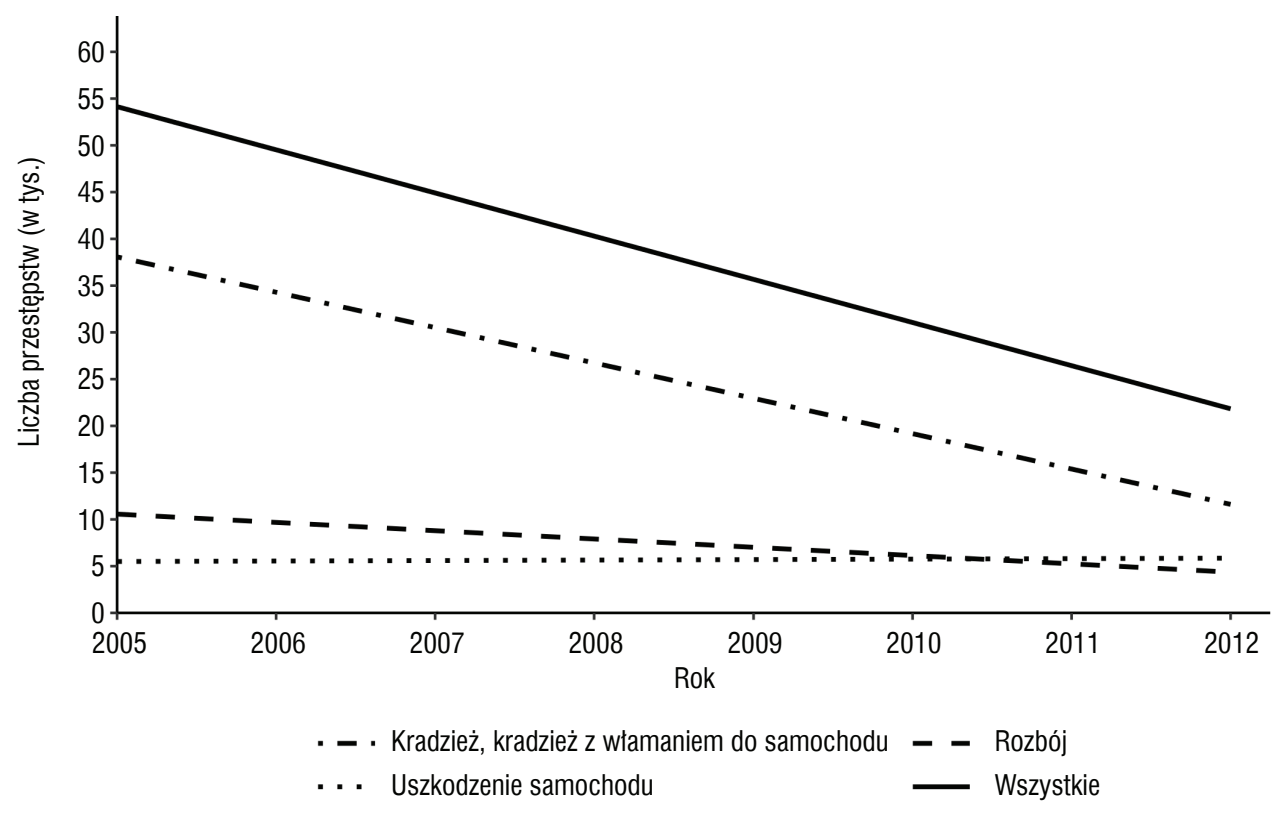

Rysunek 3. Linie trendu poszczególnych kategorii przestępstw odnotowanych w badanych miastach

Wartości $\beta$ oraz 95-procentowy przedział ufności dla regresji liniowej: Kradzież, kradzież z włamaniem do samochodu: $-10,35$ [-15,73; -4,8]; Rozbój: $-2,43$ [-3,62; -1,24]; Uszkodzenie samochodu: 0,14 [-0,47; 0,75]; Wszystkie: $-12,64[-19,38 ;-5,90]$.

Źródło: opracowanie własne na podstawie danych Policji.

Kategorie „kradzież, kradzież z włamaniem do samochodu” i „rozbój” mają ujemną wartość $\beta$ oraz cały 95-procentowy przedział ufności jest mniejszy niż zero, co oznacza, że mamy do czynienia z trendem spadkowym. Z kolei wyniki dla kategorii „uszkodzenie samochodu” są niejednoznaczne. Analizując łącznie trzy kategorie przestępstw uwzględnione $\mathrm{w}$ niniejszej analizie, w badanych przez nas miastach zauważalny jest wyraźny spadek poziomu przestępczości.

W okresie od 2005 do 2012 roku liczba przestępstw spadła z ok. 65 tys. do ok. 26 tys. Spadek ten nie był jednak równomierny. W okolicach 2007 roku krzywa na wykresie delikatnie się „wypłaszacza”. W 2008 roku spadkowy trend się odwraca, aby w 2009 r. znów opadać. W okresie objętym badaniem sukcesywnie spadała liczba przestępstw w przeliczeniu na tysiąc mieszkańców. W 2005 roku wynosiła ona 13,3 zaś w 2012 spadła do 5,1 przestępstw na tysiąc mieszkańców. 


\section{Czy spadek liczby przestępstw powoduje spadek wielkości strat?}

Wykres wartości strat wynikających z przestępstw jest w dużej mierze podobny do wykresu liczby przestępstw (rysunek 4).

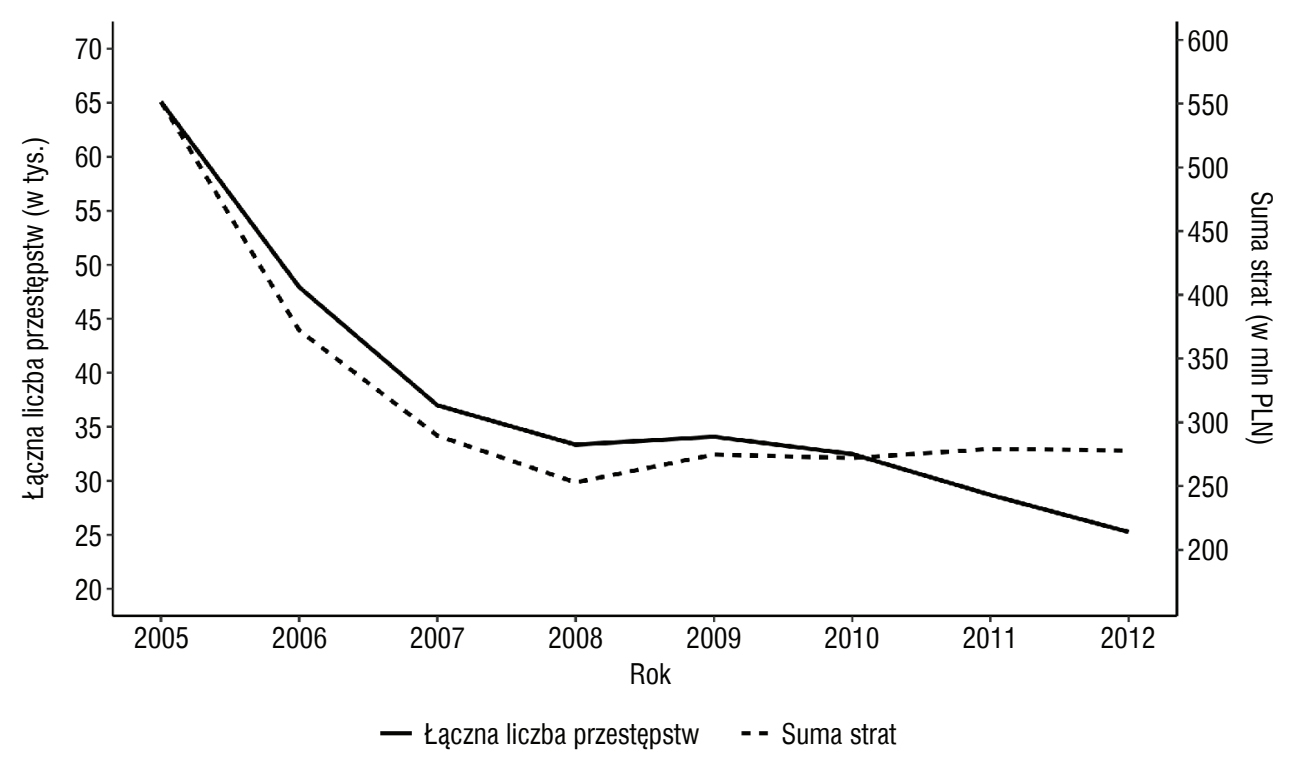

Rysunek 4. Liczba przestępstw oraz wysokość strat w ośmiu badanych miastach dla trzech kategorii przestępstw: (a) kradzież samochodu, kradzież z włamaniem do samochodu, kradzież z samochodu, (b) uszkodzenie samochodu, (c) rozbój

Źródło: opracowanie własne na podstawie danych Policji.

Między 2005 a 2008 rokiem widać wyraźny spadek wielkości strat, jakie poniosły ofiary. W tym okresie suma strat spowodowanych przestępczością maleje ponad dwukrotnie. W 2005 roku wynosiła ona ponad $551 \mathrm{mln}$ PLN, co daje około 112 PLN w przeliczeniu na jednego mieszkańca, natomiast w 2008 roku zmalała ona do prawie 253 mln PLN, czyli do 51 PLN w przeliczeniu na mieszkańca. W 2008 roku następuje moment krytyczny, w którym trend się odwraca, a suma strat wynikających z przestępstw rośnie wraz z przejściowym odwróceniem trendu spadkowego liczby przestępstw w badanych miastach, który nastąpił w 2008 roku. W przypadku strat odwrócenie trendu nie jest przejściowe. W latach 2008-2012 wartość strat wzrosła o nieco ponad 25 mln PLN. W 2009 roku średnia strata wynikająca z przestępstwa 
wyniosła około 8 tys. PLN, a w ciągu następnych czterech lat kwota ta wzrosła do około 11 tys. PLN.

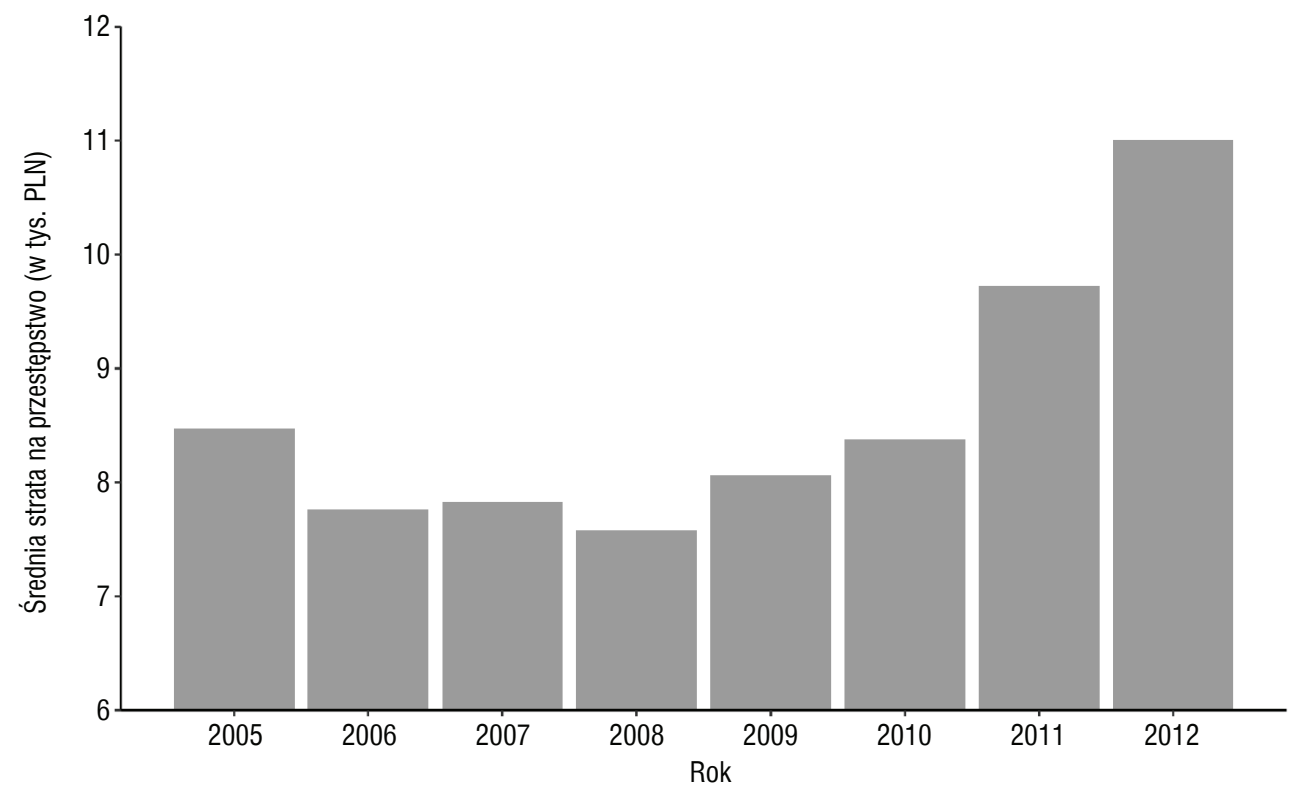

Rysunek 5. Średnia strata wynikająca $\mathrm{z}$ przestępstwa $\mathrm{w}$ badanych miastach dla trzech kategorii przestępstw: (a) kradzież samochodu, kradzież z włamaniem do samochodu, kradzież z samochodu, (b) uszkodzenie samochodu, (c) rozbój

Źródło: opracowanie własne na podstawie danych Policji.

\section{Które kategorie przestępstw odpowiadają za wzrost średniego kosztu przestępstwa?}

Wykresy strat spowodowanych poszczególnymi przestępstwami różnią się od siebie. W 2008 roku nastąpił wyraźny spadek średniej wartości przestępstwa w kategorii rozbój, jednak od 2008 roku wartość ta rośnie, podobnie jak w innych kategoriach (rysunek 6). 
(a) Kradzież samochodu, kradzież z włamaniem do samochodu, kradzież z samochodu

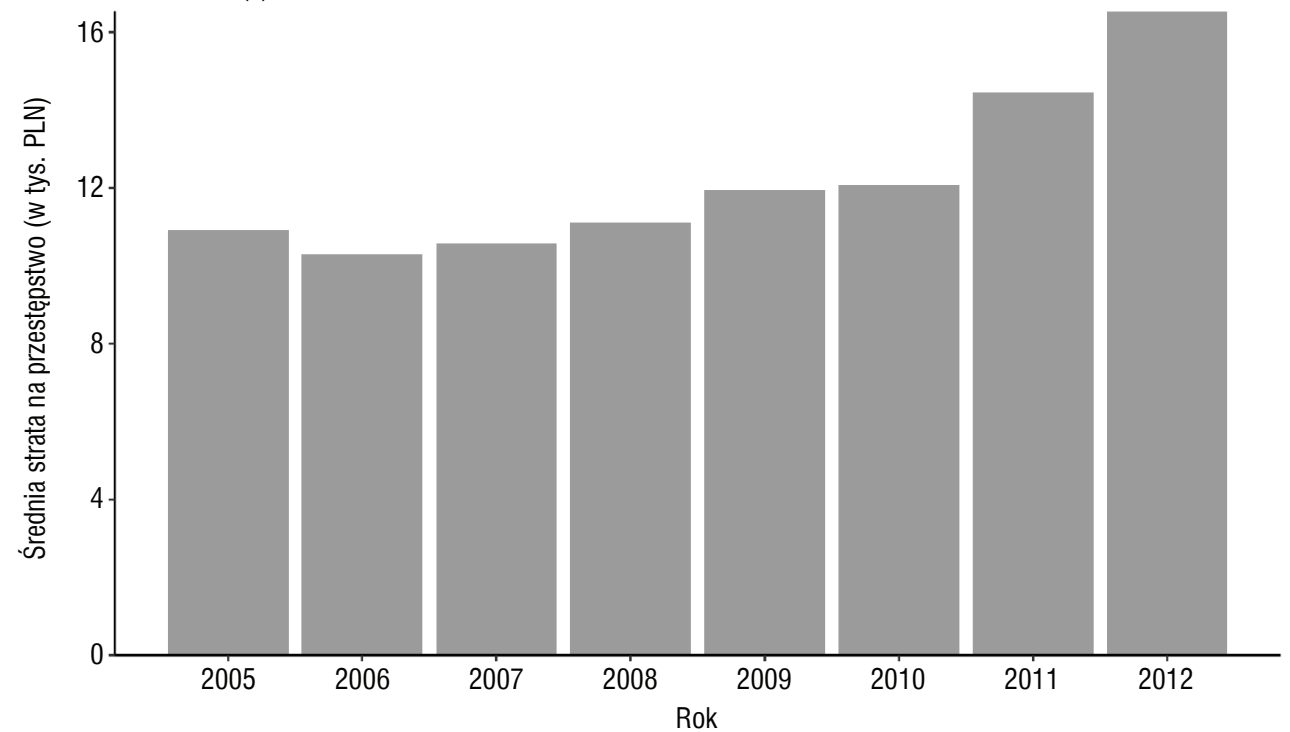

(b) Uszkodzenie samochodu

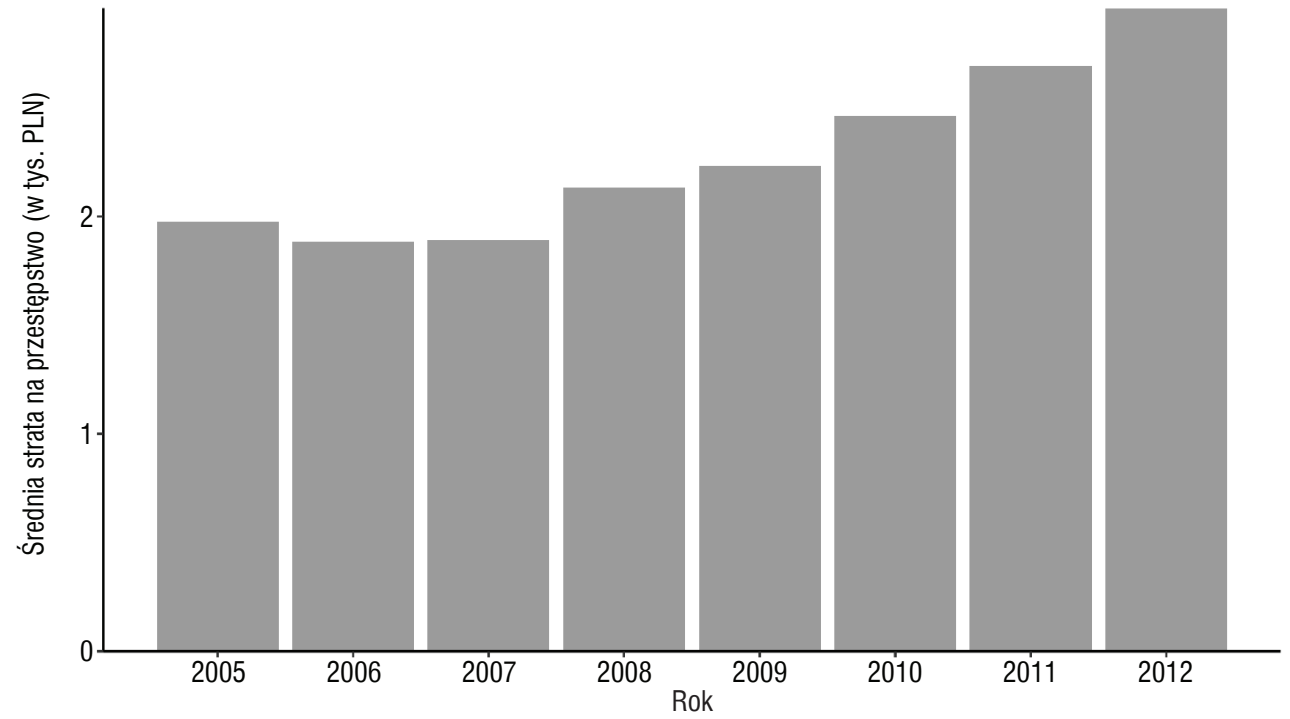


c) Rozbój

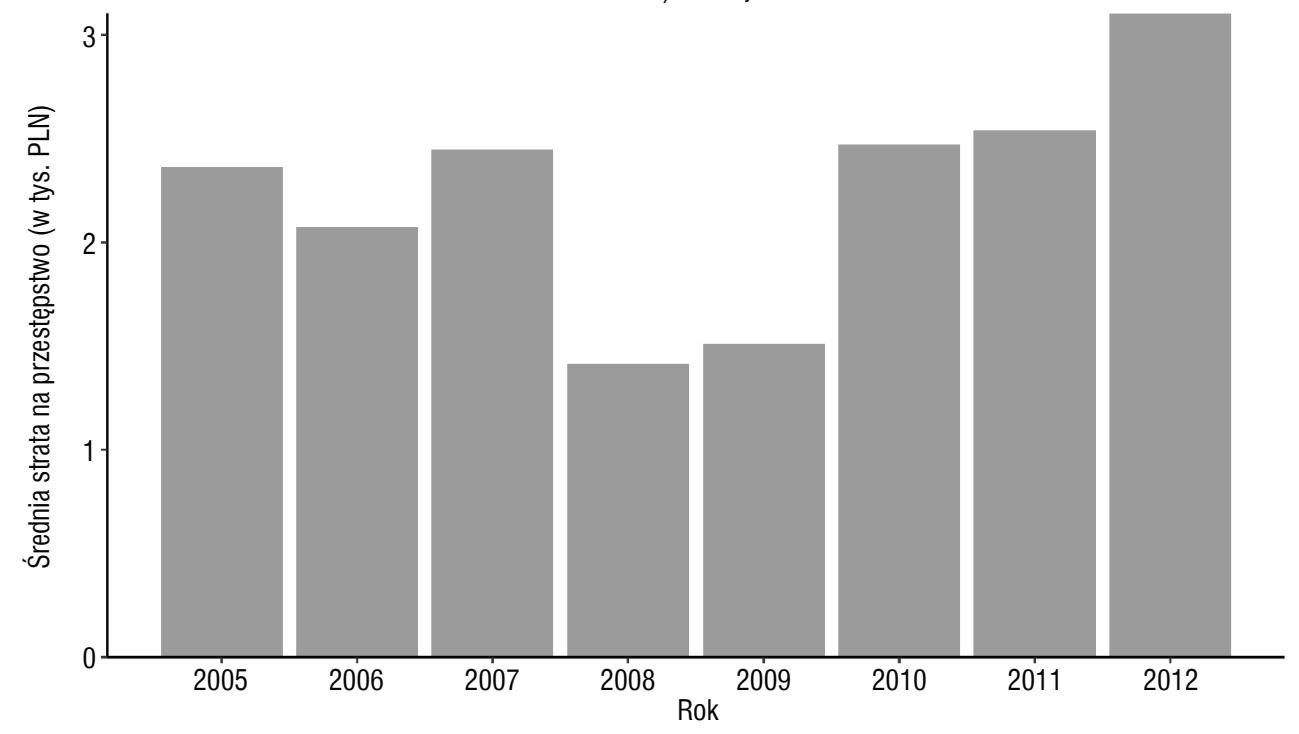

Rysunek 6. Dynamika wielkości strat dla kategorii przestępstw

Źródło: opracowanie własne na podstawie danych Policji.

\section{Dynamika przestępczości i wielkości strat a rozwój monitoringu wizyjnego}

Opisanym powyżej trendom towarzyszy niemal liniowy, biorąc pod uwagę wszystkie badane przez nas miasta, rozwój systemu monitoringu miejskiego. Skumulowany przyrost liczby kamer monitoringu miejskiego w badanych miastach (rysunek 2) wiąże się ze spadkiem liczby przestępstw (rysunek 4).

Współczynnik korelacji Pearsona między liczbą kamer a liczbą przestępstw wynosi -0,935. Z kolei współczynnik korelacji Pearsona między liczbą kamer a wielkością strat wynosi -0,864. Oznacza to, że relacja między liczbą kamer a spadkiem liczby przestępstw jest wyraźniejsza niż w przypadku związku między liczbą kamer a wielkością strat.

\section{Dyskusja i wnioski}

Artykuł stanowi wkład w dyskusję związaną ze znaczeniem prewencyjnym monitoringu wizyjnego. Polskie miasta zwalczają działalność przestępczą poprzez rozwój sieci monitoringu, która z roku na rok obejmuje swoim zasięgiem coraz większe 
obszary. Zapewnienie bezpieczeństwa mieszkańcom jest jednym z podstawowych zadań państwa oraz, w szczególności, jednostek samorządu terytorialnego. Stosowanie rozwiązań opartych na nowoczesnych technologiach nadzoru staje się coraz bardziej popularne. Jak pokazują zebrane dane, liczba kamer systematycznie rośnie w dużych polskich miastach, jednak wciąż otwarte pozostaje pytanie, na ile taka polityka ma uzasadnienie? W niniejszym artykule wskazane zostały trendy dotyczące wybranych typów przestępczości, a nacisk położono na aspekty finansowe związane z popełnianymi przestępstwami. Dynamika liczby przestępstw oraz wielkości strat odnoszona jest do rozwoju systemu monitoringu w objętych badaniem ośmiu miastach.

Przeprowadzona analiza pozwoliła uchwycić zmiany, jakie następują w badanych kategoriach przestępstw. Zebrane dane pokazują spadek poziomu przestępczości, który nie jest jednakowy dla wszystkich badanych kategorii. Najwyraźniejsza tendencja spadkowa dotyczy przestępstw samochodowych, czyli kradzieży samochodu, kradzieży z włamaniem do samochodu oraz kradzieży z samochodu. Jest to zgodne z literaturą światową, w której się wskazuje, że kategoria ta jest podatna na wpływ monitoringu (Caplan i in., 2011; Welsh, Farrington, 2009; Gill, Spriggs, 2005). Dynamika przestępstw, które można uznać za popełniane spontanicznie (uszkodzenie samochodu oraz rozbój), czyli z tzw. zamiarem nagłym, nie jest jednoznaczna. W przypadku rozboju oraz kradzieży samochodu, kradzieży z włamaniem do samochodu oraz kradzieży z samochodu większa liczba kamer łączy się z mniejszą liczbą przestępstw, zaś w przypadku uszkodzenia samochodu nie zachodzi taki związek. Liczba przestępstw zaliczonych do tej kategorii, w przeciwieństwie do pozostałych kategorii, zmienia się w sposób niesystematyczny. W latach 20072009 następuje wyraźny wzrost liczby przestępstw. Trudno jednak powiązać nagły wzrost przestępstw $\mathrm{w}$ tej kategorii $\mathrm{z}$ konkretnymi wydarzeniami. Zarówno przestępstwa samochodowe, jak i rozbój, wymagają przygotowania. Nie są to zwykle przestępstwa popełniane spontanicznie. Inaczej jest z przestępstwami z kategorii uszkodzenie samochodu, które mogą być popełniane z zamiarem nagłym (Daszkiewicz, 1968), w afekcie, często w wyniku odurzenia alkoholem bądź narkotykami, dlatego takie wykroczenia mogą być mniej zależne od działań prewencyjnych, a także uwarunkowań socjoekonomicznych.

Analiza danych sugeruje skuteczność monitoringu wizyjnego w odniesieniu do przestępstw samochodowych, zaś w przypadku kategorii przestępstw spontanicznych efekt nie jest wyraźny. Biorąc pod uwagę literaturę, która każe oczekiwać dobrego efektu w przypadku przestępstw samochodowych, zaś słabszego w przypadku przestępstw spontanicznych, można uznać, że analiza zebranych danych potwierdza tezy zawarte w literaturze. 
Spadek liczby przestępstw skorelowany z rozbudową systemu monitoringu miejskiego może wpływać na poczucie bezpieczeństwa Polaków. Poczucie bezpieczeństwa, a także spadek poziomu przestępczości są oczywiście uzależnione od wielu czynników, zaś kamery monitoringu mogą być jednym $\mathrm{z}$ nich, co jest sugerowane w literaturze (Cho, Park, 2017). Należy zwrócić uwagę na to, że spadek liczby przestępstw w Polsce obserwowany jest od 2004 roku, tj. od wejścia Polski do Unii Europejskiej. Jest to znaczący moment, gdyż w wyniku dołączenia do grona państw członkowskich UE Polacy uzyskali łatwiejszy dostęp do krajów strefy Schengen, co spowodowało wzrost migracji. To z kolei może mieć znaczenie, gdyż wyjazd młodych ludzi z kraju może być traktowany jako ewentualna przyczyna spadku przestępczości (Siemaszko, 2015).

Badania pokazują istnienie związku między wzrostem liczby kamer a spadkiem poziomu przestępczości w wybranych kategoriach. Okazuje się jednak, że spadek poziomu przestępczości idzie w parze ze spadkiem wielkości strat do roku 2008, lecz potem związek ten przestaje być wyraźny. Co prawda w dalszym ciągu spadała liczba przestępstw, ale zaczęła wzrastać średnia wielkość straty spowodowanej przez dane przestępstwo.

Można przypuszczać, że średnie straty wynikające z uszkodzenia, kradzieży i włamań do pojazdów rosną ze względu na to, że na naszym rynku rośnie średnia wartość pojazdów. Dodatkowo możliwe, że - generalnie rzecz biorąc - przestępcy zrezygnowali z drobnych wykroczeń na rzecz takich, które dają wyższe zyski. Wzrost wielkości strat po 2009 roku może być spowodowany sytuacją socjoekonomiczną w Polsce i wzrostem zamożności.

Zebrane dane pozwalają na stwierdzenie, że dostępność szeregów czasowych dotyczących przestępczości okazała się kłopotliwa. Modyfikacje w klasyfikacji przestępstw niosły ze sobą na tyle duże wątpliwości dotyczące porównywalności między poszczególnymi okresami, że zdecydowano się zrezygnować z analizy w jednym szeregu czasowym danych do 2012 roku oraz po roku 2012. Dodatkowo, brak danych dotyczących kosztów związanych z instalacją, a także eksploatacją monitoringu wizyjnego w badanych miastach stanowił utrudnienie w przeprowadzeniu badania. Ocena działania systemów monitoringu w polskich miastach wymaga dostępu do danych dotyczących kosztów przestępstw, kosztów związanych z instalacją oraz eksploatacją kamer monitoringu, a także danych dotyczących lokalizacji przestępstw i kamer. Dane te powinny być gromadzone w sposób systematyczny i z dbałością o ich jakość. Dla badaczy istotne jest, aby dane dotyczące lokalizacji kamer oraz przestępstw zawierały dokładny adres bądź współrzędne geograficzne. Przy gromadzeniu danych dotyczących kosztów związanych z monitoringiem miejskim istotne jest ujednolicenie formatu zapisu informacji tak, aby możliwe było porównywanie danych z kilku miast. Wzbogacenie wyżej wymienionych danych wymaga współpracy kilku 
różnych organów, takich jak komenda Policji, urzędy miasta, a także straż miejska, która często odpowiada za monitoring miejski.

Podsumowując, należy stwierdzić, że badanie pokazuje skuteczny wpływ systemu monitoringu wizyjnego na spadek przestępczości w analizowanych kategoriach przestępstw. W interpretacji wyników należy jednak uwzględnić po pierwsze, że istnieje wiele możliwych czynników, które obok rozbudowy monitoringu mogą mieć na to wpływ, zaś po drugie, że wpływ ten jest mniej wyraźny w przypadku wielkości strat spowodowanych przestępczością. Oznacza to, że przy ocenie polityki publicznej dotyczącej bezpieczeństwa kryterium liczby przestępstw jest niewystarczające.

\section{Bibliografia}

Aebi, M.F., Linde, A. (2010). Is there a crime drop in Western Europe?. European Journal on Criminal Policy and Research, 16(4): 251-277.

Becker, G.S. (1990). Przestępstwo i kara - podejście ekonomiczne, w: Ekonomiczna teoria zachowań ludzkich. Warszawa: Państwowe Wydawnictwo Naukowe.

Caplan, J.M., Kennedy, L.W., Petrossian, G. (2011). Police-monitored CCTV cameras in Newark, NJ: A quasi-experimental test of crime deterrence. Journal of Experimental Criminology, 7(3): 255-274.

CBOS, https://www.cbos.pl/PL/trendy/trendy.php?trend_parametr=poczucie_bezpieczenstwa (dostęp: 5.10.2018).

Cho, J.T., Park, J. (2017). Exploring the effects of CCTV upon fear of crime: A multi-level approach in Seoul. International Journal of Law, Crime and Justice, 49, 35-45.

Czabański, J. (2006). Koszty przestępczości, w: J. Czabański (red.), Bezpieczne państwo. Nowe trendy w polityce karnej: 171-186.

Czapska, J., Wójcikiewicz, J. (1999). Policja w społeczeństwie obywatelskim. Zakamycze: 5.

Daszkiewicz, K. (1968). Zamiar nagły (dolus repentinus) w polskim prawie karnym. Palestra, 12/4(124): 51-60.

Dąbrowski, A., Matczak, P., Wójtowicz, A., Leitner, M. (2018). Identification of Experimental and Control Areas for CCTV Effectiveness Assessment - The Issue of Spatially Aggregated Data. ISPRS International Journal of Geo-Information, 7(12): 471.

Dolan, P., Peasgood, T. (2006). Estimating the Economic and Social Costs of the Fear of Crime. The British Journal of Criminology, 47(1): 121-132.

Economist (2013). The curious case of the fall in crime, 20.07.2013.

Farrall, S. (2017). Outlining the Crime Drop. In Re-Examining the Crime Drop, Springer.: 1-8.

Farrell, G., Tilley, N., Tseloni, A. (2014). Why the crime drop? Crime and Justice, 43(1): 421-490.

Filaber, J. (2008). Pojęcie porządku publicznego w nauce prawa administracyjnego, w: E. Ura, K. Rajchel, M. Pomykała, S. Pieprzny (red.), Bezpieczeństwo wewnętrzne we współczesnym państwie, Rzeszów: 30. 
Gill, M., Spriggs, A. (2005). Assessing the impact of CCTV (1-176). London: Home Office Research, Development and Statistics Directorate.

Levitt, S.D. (2004), Understanding why crime fell in the $1990 \mathrm{~s}$ : Four factors that explain the decline and six that do not. Journal of Economic Perspectives, 18(1): 163-190.

Lewandowski, J., Matczak, P. (2015). Monitoring wizyjny jako narzędzie prewencji kryminalnej - analiza skuteczności systemu monitoringu w Poznaniu. Samorząd Terytorialny, 7-8: 126-143.

Lim, H., Kim, C., Eck, J.E., Kim, J. (2016). The crime-reduction effects of open-street CCTV in South Korea. Security Journal, 29(2): 241-255.

Lisiecki, M. (2009). Jakość w zarządzaniu bezpieczeństwem obywateli. Lublin: Wydawnictwo Katolickiego Uniwersytetu Lubelskiego: 13.

Mączyński, M. (1998). Samorząd terytorialny a ochrona bezpieczeństwa i porządku publicznego na szczeblu lokalnym: 185.

NIK (2014). Funkcjonowanie miejskiego monitoringu wizyjnego, https://www.nik.gov.pl/kontrole/P/13/154/LKA/ (dostęp: 5.10.2018).

Otwarte Dane, https://dane.gov.pl/dataset/1012 (dostęp: 5.10.2018).

Policja (1998), http://statystyka.policja.pl/st/raporty/roczne-raporty-statyst/47756, Raport-1998. html (dostęp: 8.11.2018).

Siemaszko, A. (2015). Atlas przestępczości 5. Warszawa: Oficyna Naukowa.

Sienkiewicz-Małyjurek, K. (2010). Rola samorządów lokalnych w kształtowaniu bezpieczeństwa publicznego. Samorząd Terytorialny, 7-8: 123-139.

Szeląg, I. (2013). Ochrona porządku i bezpieczeństwa publicznego jako zadanie własne samorządu lokalnego. Kwartalnik Naukowy OAP UW e-Politikon, 6: 162-186.

Szymańczak, K. (1998). Przestępczość w Polsce w latach dziewięćdziesiątych. Biuro Studiów i Ekspertyz, 643.

Tilley, N. (1993). Understanding car parks, crime, and CCTV: evaluation lessons from safer cities. London: Home Office Police Department.

Tonry, M. (2014). Why crime rates are falling throughout the Western world. Crime and Justice, 43(1): 1-63.

Waszkiewicz, P. (2012). Monitoring wizyjny miejsc publicznych w dużym mieście na przykładzie Warszawy. Próba analizy kosztów i zysków. Archiwum Kryminologii, XXXIV: 253-273.

Welsh, B.C., Farrington, D.P. (2003). Effects of closed-circuit television on crime. The Annals of the American Academy of Political and Social Science, 587(1): 110-135.

Welsh, B.C., Farrington, D.P. (2009). Public area CCTV and crime prevention: an updated systematic review and meta-analysis. Justice Quarterly, 26(4): 716-745.

Artykuł powstał w wyniku realizacji projektu badawczego o nr 2016/21/B/HS6/01158 finansowanego ze środków Narodowego Centrum Nauki. 